\title{
Poética e icónica trinidad: Ismael Nery, Murilo Mendes y Jorge de Lima
}

Laura Cabezas ${ }^{1}$

Enviado em: 04/09/2018

Aceito em: 20/03/2019

Resumo: El artículo explora las relaciones entre la poesía y el arte, de sustrato moderno, y el catolicismo en auge en Brasil, en los años treinta, a través de las figuras de Ismael Nery, Murilo Mendes y Jorge de Lima. La hipótesis que guía el recorrid o sostiene que ambas configuraciones -la estética y la religiosa- comparten una misma preocupación: el cuestionamiento de la representación y el rechazo a lo puramente visible. En este sentido, el ícono, y su relación con el cuerpo de Cristo, se recorta como un modo de lectura privilegiado para las obras de Nery, sus poemas y el libro en colaboración de Mendes y Lima, Tempo e eternidade, dedicado al amigo artista ya muerto.

Palavras-Chave: Ismael Nery; Murilo Mendes; Jorge de Lima - Icono - Tempo e eternidade

Abstract: The article explores the relationship between poetry and art, of modern substrate, and the Catholicism that was booming in Brazil, in the thirties, through the figures of Ismael Nery, Murilo Mendes and Jorge de Lima. The hypothesis that guides the journey maintains that both configurations - aesthetic and religious - share the same concern: the questioning of representation and the rejection of the purely visible. In this sense, the icon, and its relationship with the body of Christ, is cut out as a privileged reading mode for the works of Nery, his poems and the book in collaboration of Mendes and Lima, Tempo e eternidade, dedicated to the artist friend already dead.

Keys words: Ismael Nery; Murilo Mendes; Jorge de Lima; Icon; Tempo e eternidade

\section{Catolicismo de vanguardia}

En torno a la pregunta "¿Hay una vuelta en la intelectualidad del mundo hacia el Catolicismo?”, el periódico español La Gaceta Literaria dedica un número especial a la relación entre catolicismo y literatura en abril de 1928. Entre las intervenciones, que se inscriben en diferentes tradiciones2, un artículo de Manuel Abril (1928, p. 6) se destaca por su llamativo título "El arte moderno y los católicos". En él, el ya reconocido crítico de arte moderno subraya un hecho en apariencia extraño: que las tendencias más avanzadas de arte plástico, como el cubismo, encuentran "sus defensores más tenaces, y al mismo tiempo más firmes

\footnotetext{
${ }^{1}$ Universidad de Buenos Aires. Licenciada y Profesora en Letras de la Universidad de Buenos Aires. Ayudante de la cátedra de Literatura Brasileña y Portuguesa (UBA- Cátedra Gonzalo Aguilar). Doctoranda de la Facultad de Filosofía y Letras (UBA). E-mail: lau.cabezas@gmail.com.

${ }^{2}$ Desde diversas perspectivas se intenta dar cuenta de los modos en que se inscribe el fenómeno religioso en el ámbito cultural, así se publican, por un lado, una gran cantidad de artículos, algunos más políticos que buscan colocar al catolicismo como una alternativa frente a las ideologías de derecha o izquierda (José Bergamin y Ángel Ossorio), otros más bibliográficos que exploran el misticismo español (Pedro Saiz Rodriguez y Fray Luis Getino), y un último grupo que funcionan como postales europeas sobre la incidencia del catolicismo en Cataluña, Portugal, Inglaterra, Alemania, Italia y Francia. También se publica una encuesta sobre el presente y porvenir del catolicismo en España, un poema de Max Jacob, una entrevista a Jacques Maritain y la transcripción de algunas de sus cartas con Jean Cocteau.
}

https://periodicos.unifap.br/index.php/letras Macapá, v. 8, n. 4, $2^{\circ}$ sem., 2018 
y finos, entre los publicistas católicos”. La extrañeza radica, para Abril, en que debe suspenderse la hipótesis según la cual un católico antepondría su concepto religioso (y moral) ante todo -ideal del ascetismo que coloca al mundo como enemigo- y que, por eso, privilegiaría el arte sacro, lleno de grandes emociones y lecciones de índole espiritual. Por el contrario, son los "artistas católicos" quienes mejor entendieron el arte nuevo que se presenta como "un mero esteticismo, como un puro divertissement estético, sin contenido formulado; mero deleite de arte que ni enaltece, ni glosa, ni divulga las glorias superiores del alma y de la mística" (ídem). Desde este razonamiento, la categoría de "espíritu" es la clave formal que habilita la posibilidad de un arte puro e irrepresentativo:

\begin{abstract}
Allí donde hay arte, hay espiritualidad, según nosotros; la obra de arte lo es en tanto en cuanto espíritu; pero con las obras representativas ocurre que, si bien pueden, como todas, patentizar, en tanto en cuanto artísticas, la existencia del espíritu, llevan mezclada, sin embargo, en tanto en cuanto representación, una ganga de elemento confusionario, ajeno, de materialismo, de naturalismo, y parece que no son esos elementos los que contribuyen a la formación del arte, perjudicando, en consecuencia, y enturbiando la intervención decisiva y exclusiva que tiene en el coro artístico el fenómeno espiritual (idem).
\end{abstract}

El arte puro que, como "emoción primaria, elemental, original", se sostiene sobre un principio espiritual extrema el gesto antirrepresentativo, en tanto "procede de una proporción de masas, líneas, pesos, calidades y cadencias, ya sean de orden musical, ya de orden plástico", es decir, ese arte vive a través de las leyes de armonía que preceden toda forma o figura representativa. Por ello, concluye Abril, en la naturaleza hay belleza, pero no todo es bello: "Es mentira que por ser natural una forma es bella" (ídem), hay leyes anteriores a las formas, leyes a priori de lo material y natural.

Dos números más tarde llega la respuesta del escritor Antonio Espina, que años más tarde ocupará las filas republicanas. El argumento central de Espina radica en la imposibilidad de pensar la religión católica por fuera de la idea de tradición, pues, según él, el análisis de las grandes obras modernas demostraría que, salvo excepciones, ninguna podría ser aceptada por la más indulgente ortodoxia católica. En pocas palabras, sentencia que las conclusiones de Abril son falsas y que podrían sintetizarse de la siguiente manera:

La tendencia insidiosa del artículo de Manuel Abril parece concretarse en un argumento totalista que podría resumirse de esta forma: En arte, lo más irrepresentativo es lo espiritual. El arte moderno es el más irrepresentativo de todos los artes a través de la historia. Por lo tanto, es el más espiritual, dentro y fuera del arte, resulta el catolicismo. Luego: el arte moderno es católico, posee una estructura católica. (1928b, p. 7)

Más allá de su carga irónica, la fórmula realmente podría funcionar en su carácter explicativo: si lo espiritual se posiciona como un significante vacío que, de modo recurrente e inestable, expresa el rechazo de la perspectiva materialista y referencial del objeto estético, el catolicismo que hace de la espiritualidad su núcleo fundante acogería sin conflicto al arte nuevo que llevó a cabo de forma radical la crisis de la representación. En este sentido, el arte moderno no sería ni católico ni anticatólico, como le responde Abril en el número siguiente; la lógica es inversa: contra todo pronóstico, la tradición católica posee un diseño estructural lo suficientemente amplio como para que ingresen los experimentos modernos. Así lo explica Manuel Abril (1928b, p. 7): 
Se trataba, pues, no de estrechar las ideas libres y laicas para hacerlas entrar en la angostura del catolicismo, sino de hacer notar que anchura del catolicismo era en este punto de holgura suficiente para que cupieran en él las ideas libres tal y como pueden profesarlas y, en efecto, las profesan muchos artistas e ideólogos modernos que no tienen ni pizca de católicos.

Se podría pensar que esta “anchura” del catolicismo encuentra, al otro lado del continente, una manifestación casi programática en el derrotero vital y plástico del artista brasileño Ismael Nery, y en las "enseñanzas" que lega en sus amigos-discípulos: Murilo Mendes y Jorge de Lima.

\section{Formas de vida e imágenes poéticas}

Entre tua eternidad e o meu espirito

se balança o mundo das formas.

Não consigo ultrapassar a linha dos vitrais

pra repousar nos teus caminhos perfeitos.

Meu pensamento esbarra nos seios, nas coxas e ancas das mulheres,

pronto.

Estou aqui, nu, paralelo à tua vontade, sitiado pelas imagens exteriores.

(..)

Vestidos suarentos, cabeças virando de repente, pernas rompendo a penumbra, sovacos mornos, seios decotados não me deixam ver a cruz.

Me desliguem do mundo das formas!

"O poeta na igreja", Murilo Mendes

Las notas biográficas que escribe Murilo Mendes años después de la muerte de Ismael Nery iluminan el efecto que produjo conjugar su condición de artista moderno con la fe católica, en un contexto intelectual que, según Murilo, veía al catolicismo como algo ya obsoleto, definitivamente caduco, sinónimo de oscurantismo y fundamento de la reacción. En una de sus primeras crónicas publicadas en O Estado de S. Paulo 3 , se lee:

Ismael voltou a Paris em 1927 e fez conhecimento pessoal com alguns escritores e pintores surrealistas. Mas, apesar de lhe interessarem muito as idéias novas, permanecia firme na sua fé, que considerava apoiada sobre um valor absoluto, definitivo e eterno. Do comunismo adotava certas partes que lhe pareceram muito justas, mas o rejeitava como norma de vida e concepção filosófica do homem e da natureza humana. Considerava infantil e ingênuo pretender fazer qualquer restricção ao Cristo e ao Evangelho. Apresentava-nos o Cristo não só na sua divindade, mas também na sua humanidade, mostrando constantemente a verdade da encarnação e ainda o Cristo como filósofo e modelo supremo dos poetas e dos artistas. Em diversos atos e passagens da sua própria vida, transpôs certos exemplos e ensinamentos do Cristo, dando-lhes atualidade viva, provando, assim, sua permanência e perenidade. Pouco a pouco, apesar de nossa rebeldia e nossas indecisões, começamos a perceber que o Evangelho não era um livro remoto e "superado", mas uma fonte de vida, pois contém a doutrina d'Aquele que se declarou a própria vida. O Cristo passou a ser, para mais alguns homens, uma realidade fortíssima, a realidade mesma. Era, portanto, possível ser em 1930 grande artista, homem moderno e católico romano de confissão e comunhão frequente. Assim foi Ismael Nery. (Mendes, 1996, p. 27 28)

\footnotetext{
${ }^{3}$ Son en total 17 entregas que hace al diario O Estado de São Paulo entre 1946 y 1949 y que luego serán agrupadas en forma de libro, titulado Recordaçoes de Ismael Nery.
} 
Si, como señala Furio Jesi (2014), del pasado lo que verdaderamente importa es lo que se olvida, ya que lo que se recuerda es tan solo sedimento y escoria, y lo que es destinado a sobrevivir, sobrevive en secreto, como presente viviente y no como memoria de pasado muerto, en el relato de Murilo el Evangelio, y su actualidad anacrónica, pone en escena un olvido fundamental: que el cristianismo diseñó una máquina universal de dislocación que inauguró no sólo una nueva coordenada espacio-temporal tan dicotómica como infinita, sino también la posibilidad de experimentar con el cuerpo hasta llegar a límites desconocidos al momento. En otra de sus entregas, Murilo apuntula: "Esses membros deslocados do corpo não foram no fim das contas inventados por Chagall; quantas antigas imagens populares ou pinturas se podem ver de santos com os membros separados da cabeça!” (ibídem, p. 119). Con lucidez, Murilo detecta a la religión como un archivo del que emanan imágenes tan actuales y potentes como las que explora el surrealismo chagalliano ${ }^{4}$.

Cosmopolita y católico, la ubicación de Nery en el mapa cultural del período es bastante marginal, tal como lo presenta Denise Mattar (2015, p. 2):

Nery nadava contra a corrente não só dos acadêmicos como também dos modernistas: sua obra nunca buscou o social nem o belo; também não pregou uma ruptura drástica com o passado, como pregava o discurso moderno. Místico e católico quando a intelectualidade defendia o ateísmo, ele construiu um vocabulário plástico universal no mesmo momento em que seus pares mergulhavam de cabeça no nacionalismo.

En efecto, con poca intervención pública, y con mucha obra pictórica y poética que se conoce luego de su temprana muerte, Nery auspicia como centro de reunión de la bohemia carioca de fines de los años veinte que congrega al ya aludido Murilo Mendes y a, entre otros, Mário Pedrosa, Antônio Bento, Guignard, Cícero Dias, Aníbal Machado, Jorge Burlamaqui y Jorge de Lima. Así lo recuerda Pedrosa (1998, p. 197-198):

\begin{abstract}
Nos idos de vinte, sua casa vila, em São Clemente, era um lugar de reunião para um pequeno grupo de moços entusiastas em torno dele. (...)

Creio poder afirmar que, entre todas as suas atividades a que mais prendia Ismael era falar à rédea solta, quando sustentado por uma audiência em que confiava. Dizia então as coisas mais inverossímeis e as mais profundas. (...)

A natureza, ou a rigorosa preparação religiosa que tinha (era católico praticante), coisa raríssima naquela época, o levava o discorrer apoiado em conceitos tirados em geral da filosofia tomista. As profundas preocupações religiosas de um ser absolutamente pagão como ele o faziam viver num permanente debate entre Deus e a criatura, entre o pecado e o viver. De um paganismo caloroso, feito de enraizado amor ao corpo, ao corpo humano, como vivencia e como forma absoluta, decorria esse sensualismo profundo, essencialista, una dialética em que tinha de terçar armas com as noções mais idealistas e abstratas do ideário católico. Em tudo procurava ele a forma ou a definição, e, necessariamente, a antiforma e a antidefinição, que ia discernir na matéria ainda não chegada à forma, ou na forma em marcha para o dilaceramento ou a dissolução.
\end{abstract}

Esta atracción por la forma definida y su disolución en lo informe o en lo indefinido se puede apreciar en uno de los dibujos que Nery realiza en tinta china llamado "Os amigos". A través de la superposición, se trazan cuerpos desnudos abrazados que delinean y

\footnotetext{
4 Silviano Santiago (2014), en el postfacio a Poemas de Murilo Mendes, refiere justamente a la tendencia de la crítica de incluir los poemas de Murilo en el ideario surrealista a causa de no existir una etiqueta vanguardista disponible que comprendiera su compromiso con la tradición medieval (en un momento en que dominaba la noción de ruptura) y con la visión cristiana/franciscana de fusión (en una época laica).
} 
quiebran los límites de sus propias figuras corporales; por su parte; una escritura semioculta bosqueja algunos de los nombres anteriormente mencionados.

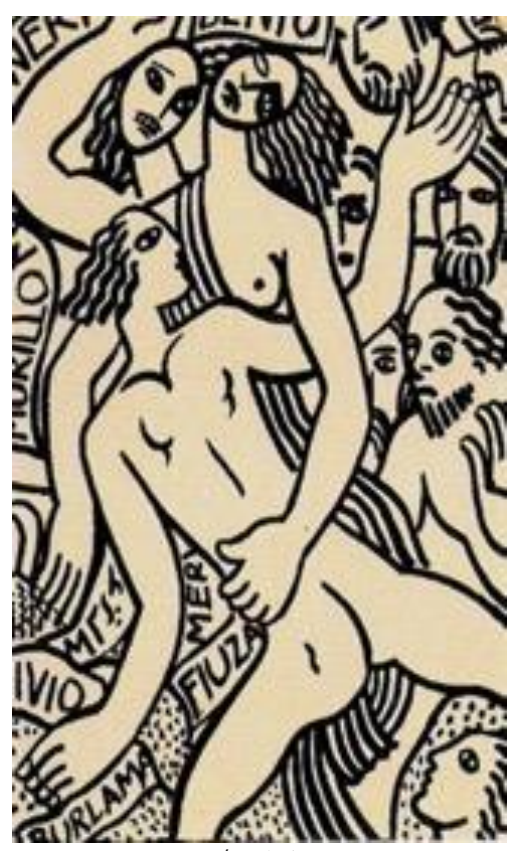

Fig. Ismael Nery, Os amigos. s/f. Tinta china sobre papel. $23,5 \times 16 \mathrm{~cm}$. Col. Gilberto Chateaubriand.

En la disposición formal se vuelve transparente la referencia al descenso de Cristo, pintado por Caravaggio entre los años 1602-1604, que aquí se presenta bajo los contornos de un cuerpo femenino que alude a la androginia como identidad primigenia, uno de los temas preferidos de Nery. Os amigos, en este punto, propone, en sintonía con el contexto del pintor italiano ${ }^{5}$, un lazo que recupere la fe sencilla, desnudada de ritualidades, que detenta el espíritu comunitario de la Iglesia primitiva cristiana. Mas que pagano como lo califica Pedrosa, el catolicismo de Nery se inscribe anacrónicamente en el imaginario de un cristianismo primitivo, previo a la normativa de la institución romana, en el que Iglesia es por definición comunión de fieles, en pie de igualdad, luchando casi revolucionariamente alrededor del Mesías asesinado. De ahí la importancia dada al Nuevo Testamento que Murilo destacaba en el fragmento citado.

Pero la militancia por Cristo no sólo implica la postulación de una ética cristiana desde la cual vivir el presente, también conlleva una teoría de la imagen que, en torno al ícono, se presenta altamente productiva en el diseño poético de Murilo Mendes. En este sentido, si el epígrafe tomado del poema "O poeta na igreja" nos presentaba, trágicamente, la

\footnotetext{
${ }^{5}$ El historiador de arte Andrew Graham-Dixon (2012) se explaya sobre la génesis de la pintura de Caravaggio: “Sólo otra pintura de Caravaggio puede datarse en 1604. Se trata de El descendimiento de la cruz, un gran y ambicioso retablo para la iglesia de los oratorianos de Roma, Santa Maria in Vallicella, situada unos cientos de metros al oeste de la Piazza Navona, cerca del lugar en el que el Tíber serpentea al lado del Vaticano. Lo terminó poco antes del 1 de septiembre, cuando la pintura es calificada de 'nueva' en un documento que certifica su adquisición por un hombre llamado Girolamo Vittice. Girolamo la había encargado para la capilla funeraria de su tío, Pietro, muerto en 1600. Como muchos de los patronos más importantes del pintor, la familia Vittrice estaba estrechamente relacionada con los oratorianos de Filippo Neri y por tanto eran aliados directos del sector pauperista, explícitamente populista, de la Iglesia romana. Pietro Vittrice había estado muy próximo al propio Neri y había apoyado los valores centrales de los oratorianos, con su énfasis en las obras de caridad, su antipatía hacia los rituales elaborados y su ambición de recuperar la fe sencilla y directa asociada con la Iglesia primitiva" (s/p).
} 
figuración de un yo poético atrapado en la intersección del mundo de las formas con el llamado informe y eterno de Dios, la salida de esa exterioridad profana se dará a través del contacto con la "filosofía" de Nery que Murilo denomina esencialismo y la construcción de una "nueva mirada" icónica que le hace justicia a la fórmula de Espina: la poesía moderna muriliana se consolida espiritualmente antirrepresentativa en el momento en que se choca con el particular catolicismo del artista plástico.

La primera participación de Murilo Mendes en la revista A Ordem se produce en 1934 con la publicación de los poemas del ya fallecido Ismael Nery y sus comentarios sobre los textos poéticos que son, más bien, junto con un pequeño ensayo de Jorge Burlamaqui, intentos por explicar la "filosofía" del artista:

O essencialismo é uma theoria philósophica e artística creada por Ismael Nery sobre bases catholicas. Ismael imprimiu-lhe o caracter da sua fortissima personalidade, sujeitando-a, porém, aos eternos princípios do catholicismo. (...) O problema actual consiste em fazer com que o homem restabeleça conscientemente o equilibrio harmonioso que necessariamente deve existir entre o espirito e a matéria. (...)

A vida é uma fornecedora de elementos constructivos que o homem consegue percorrendo uma serie de momentos que se nos apresentam todos com perspectivas e propriedades particulares em seu encadeamento lógico. Por imperfeição de sentidos, o homem necessita agrupar momentos, afim de que melhor se constatem differenças (épocas, idades, etc.). Estudando a vida, isto é, a totalidade destes momentos, chegamos a conclusão de que verdadeiramente o homem não se póde representar nem ser representado com as perspectivas e propriedades de um só momento, pois, seria sempre uma representação fragmentaria, portanto, defficiente para o conhecimento. O homem deve representar sempre em seu presente uma somma total de seus momentos passados. A localização de um homem num momento de sua vida contraría uma das condições da vida, que é o movimento. Se pegarmos a esmo, dentro de sua vida, um homem, em momentos distantes, elle nos dará impressão de coisas differentes, tanto mais diversas quanto maior for o afastamento dos momentos, impressão impossível com a organização dos momentos que determinaram esta evolução. O essencialismo dá uma grande importância á abstracção do tempo, que não é outra cousa señão a reducção dos momentos necessária á classificação dos valores para uma compensação absoluta. (A Ordem, №56, marzo de 1934, p. 422)

Como uno de los cuadros de Nery, Murilo denomina "esencialismo" a la estructura teórica que sustenta pensar la vida como una construcción dinámica que concilia de modo armónico materia y espíritu, y a la vez reclama la necesidad de abstraerse de los condicionamientos de la perspectiva de un solo momento ${ }^{6}$. No hay evolución posible, el movimiento como motor vital impone un presente total y pleno que se libere de las amarras de los momentos históricamente trazados: una imagen epifánica que corte el espacio-tiempo y relampaguee en un instante eterno. En el poema en prosa que Murilo comenta, "Poema post-essencialista", se suceden diversos recorridos sobre un mundo deshabitado primero y luego poblado, a través de un yo que se multiplica y percibe/se percibe en el ritmo que se forja entre vida exterior e interioridad:

\footnotetext{
${ }^{6}$ El comentario de Murilo se acompaña de un artículo de Jorge Burlamaqui “Abstracção do espaço e do tempo" que, fue escrito bajo la mirada y aprobación de Nery. En el texto, Burlamaqui desarrolla in extenso lo presentando por Murilo y se detiene en explorar un método que le permita al individuo eliminar lo superfluo de lo esencial. Lo llama: la posición en el espacio y tiempo justos. Para llegar a la verdad, se debe considerar los hechos por fuera de la existencia particular de cada hombre en un momento que también se ubique por fuera del propio presente, para así comprender todos los efectos y las repercusiones de sus acciones. (ibídem, p. 424-28)
} 
Existe apenas eu mesmo, que me percebo inversamente por uma idea que chamo mulher e que para rarefeita sobre a superfície do globo - idea incomprehensivel porque nada existe na terra além de mim mesmo. Volto a percorrer novamente o espaço, porém, desta vez, com a lentidão do crescimento das plantas, multiplicando-me progressivamente na minha idea para mostrarme a mim mesmo. (A Ordem, No57, febrero de 1934, p. 87).

En Nery la vida como totalidad toma, en numerosas ocasiones, la forma del germen que se debate dialécticamente entre la construcción y la destrucción, delineando una potencia de ser que nunca se concretiza en acto, o una potencia divina que excede las formas dadas. En otro de los poemas en prosa transcriptos por Murilo Mendes se lee: "Pertenço a esta espécie de homens que não constroem nem destroem, mas que dão a razão de toda a construcção e de toda destruição (...) Através dos séculos deveremos desenvolver o germen que, no principio da vida, recebemos"1 ("Última página”, ibidem: 185). Es verdad que la Biblia no da una definición de qué es la vida, sino que en realidad sostiene la equivalencia entre Dios y el Viviente eterno, que da vida y no puede morir: a diferencia de las religiones antiguas pero también de los ídolos, Dios está vivo 7 . Esta vida se hace "carne espectral" (Ludueña, 2012, p. 131) en la figura humana y divina de Cristo que inaugura la pregunta sobre la posibilidad de representar el poder vivo de lo espiritual. Transmitir la vitalidad crística en sus imágenes poéticas, será una de las tareas que llevarán a cabo Murilo Mendes y Jorge de Lima en Tempo e eternidade.

\section{El poema como objeto icónico}

La querella iconoclasta, que se expande en el Imperio bizantino entre los siglos VIII y XIX d.C., es el momento en que resuena repetidamente un interrogante: si Dios se había hecho visible como hombre, ¿su representación en imagen también era posible? Es necesario tener presente que no se trata de una batalla entre partidarios y detractores de la imagen, sino de los alcances de la visibilidad de lo sagrado. En efecto, la disputa se da entre quienes defienden la imagen consustancial -invisible- contra quienes promueven el ícono mimético -visible en los modos de acceso a la manifestación de lo divino. Como expone Fabián Ludueña (2012) siguiendo a André Grabar, León XIII rechazaba la imagen de Cristo no porque estuviera contra la imagen en sí, sino porque el ícono artificial estaba desprovisto de respiración y voz; en otras palabras, porque no se trataba de una imagen "viva", poseída por el espectro crístico. Sin embargo, los defensores del ícono asumían la figuración de la propia vida (Mondzain, 2013. Traducción nuestra) de Cristo a través de su cuerpo glorioso que no contradecía el desprecio por la carne, sino que, por el contrario, exponía espiritualmente la victoria por sobre el pecado, el sufrimiento y la muerte. Es que si la imagen es siempre independiente de la visibilidad, el ícono propone mirar lo invisible; en palabras de Marie-José Mondzain (2013, p. 117):

O ícone não está no mistério teológico, mas no enigma econômico. Nele, o Verbo desposa a carne, a vos fecunda o corpo. Quem compreende isso assume a força do olhar e renuncia a dizer, ingenuamente, que só acredita no que vê, ou que só vê o que é visível. Assim se instaura a primeira ideia do olhar para o ícone como primeira ideia do olhar invisível que provém da

\footnotetext{
${ }^{7}$ En el Deuteronomio, se llama a la divinidad "Dios vivo" (como en Dt 5, 26) contraponiendo este concepto al de los ídolos que, se nos dice, no tienen vida. Lo mismo veremos en el libro de la Sabiduría en el que este argumento de que no tienen vida, será de nuevo uno de los principales que se utilizan contra los ídolos: “tuvieron por dioses a todos los ídolos de las gentes, cuyos ojos no les sirven para ver, ni pueden respirar el aire por sus narices, ni oyen por sus oídos, ni los dedos de sus manos sirven para tocar" (Sab 15, 15).
}

https://periodicos.unifap.br/index.php/letras Macapá, v. 8, n. 3, $2^{\circ}$ sem., 2018

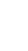


própria imagem e é concedido por ela. Os componentes do ícone convocam o olhar e rejeitam a visão, sem, no entanto, quererem enganá-la.

"Restauremos la poesía en Cristo" es el epígrafe que Murilo Mendes y Jorge de Lima eligen para un libro de poemas publicado en conjunto en 1935, Tempo e eternidade, dedicado a Ismael Nery. En dúo construyen un objeto literario en colaboración que da cuenta de su experiencia religiosa, una suerte de testimonio que se lanza al mercado editorial para sentenciar su pasaje al catolicismo. Dos secciones organizan el material poético, primero se presentan los poemas de Jorge de Lima, el gran poeta modernista del Nordeste, que dan cuenta del regreso a una cierta religiosidad popular asomada en la infancia que se combina con sucesivas alusiones al Evangelio; luego se suceden los poemas de $\mathrm{Mu}-$ rilo Mendes ligados a la violencia esencial de una espiritualidad religiosa de tinte apocalíptico ${ }^{8}$. Esta estructura bipartita que les valió a los autores en ese momento los motes burlones de "Tiempo" - para Lima- y "Eternidad" - para Mendes-, también condujo a la crítica a leer por separado un libro que se concibió en conjunto"; como explica Fábio Andrade (2002), estos sobrenombres:

faziam eco à clara delimitação sugerida pela crítica contemporânea (particularmente Lúcia Miguel Pereira e Tristão de Atayde), colocando, de um lado, uma poesia terrena, de lamento e súplica aspirando à eternidade e à libertação, e, do outro, a celebração do eterno de um ponto de vista que despreza o tempo, alçando-se a uma perspectiva quase divina. Tratava-se de uma abordagem contrastiva cujo fundamento estava mais nas trajetórias anteriores dos poetas e que enfatizava antes as diferenças das efígies impressas do que o fato de formarem lados de uma mesma moeda. Como consequência, arriscava-se a perder de vista a nova configuração temática e estilística que "Tempo e Eternidade", ainda que timidamente, sugeria: um catolicismo milenarista e escatológico, voltado para a gênese e o apocalipse, conferindo ao poeta o papel de um pequeno demiurgo, criador de realidades autônomas. (ANDRADE, 2002, p. 98)

La configuración del poeta como demiurgo involucra la composición de obras cósmicas que siguen el rastro de una pureza constructiva, que en este caso puede leerse como la evasión de la autoría única como dogma. Si "el genio sólo se declina en singular", como se lamentan Michel Lafon y Benoît Peeters (2008, p. 7) en su famoso libro sobre la escritura en colaboración, aquí la salida del yo singular se produce a partir de la creencia religiosa que conlleva la disolución de los sujetos en un Otro, una entidad absoluta y superadora de las dicotomías.

Así, pese a esa estructura contrastiva que Tristão de Athayde (1935) traza al inicio de su texto crítico, respetando la individualidad de los nombres propios, puede detectarse cierto intento por aunarlos bajo la opción por una poesía moderna y católica que se escribe sin ornamentos, siguiendo las líneas rígidas y arquitectónicas de una iglesia. Cito en extenso:

Ela aparece [la poesía de ambos], nessas páginas, curtas mas impressionantes, despida de todo pieguismo, vazia de qualquer artificio visível ou de ornato supérfluo, numa revelação puríssima da beleza do mundo tal como a exprime o dogma católico. Porque êsses poemas refletem diretamente a beleza dogmática da Verdade. Suas linhas são lisas, altas, diretas, rudes, como as da própria figura da Igreja tão desfigurada pelo Romantismo devoto ou pela paixão sectária. Há poemas curtos e fáceis, verdadeiros pontos de exclamação poéticos. E há poemas longos e

\footnotetext{
${ }^{8}$ El libro se divide en cuarenta y cinco poemas de Jorge de Lima y treinta y seis de Murilo Mendes.

${ }^{9}$ Una de las explicaciones de la insistencia de la crítica en analizar las secciones por separado privilegiando las autorías individuales puede ser que el libro no tuvo reediciones y que los poemas de cada autor se incluyeron en sus respectivas obras reunidas y/o completas.
} 
salmodiados, que nos levam por suas asas possantes, ao longo dos tempos e à luz da eternidade. Poesia objetiva, mas sem sombra de preocupação, de preocupação descritiva ou panteísta. Poesía hierática, mas sem frieza. Poesia católica, essencialmente católica, poesia episcopal, desassombradamente eclesiástica e pontifícia, na mais bela acepção dêsses têrmos -sem qualquer vislumbre de sentimentalismo devoto ou de falso classicismo.

Moderna, extremadamente moderna, mas sem qualquer Modernismo artificial (...) Folgo, pois, em poder aproximar nesta crônica páginas, de poesia e de prosa, que marcam, para a literatura brasileira, um dos mais altos cimos de sua grave inspiração moderna, nesta hora em que os ornatos caem; os malabarismos se desmoralizam; volta-se às coisas essenciais e certas almas desenganadas das aventuras intelectuais literárias levantam o véu do mistério e param estupefatas, pressentindo ou descobrindo a Fonte suprema da beleza e da explicação de todas as coisas.

Por muitos anos pedi aos modernos não fecharem os olhos ao sobrenatural, lado direito do tecido de que somos apenas o avesso. Ei-lo aqui, o sobrenatural. ("A Desforra do Espírito", en O Diário, 23 de junho de 1935)

Según el crítico brasileño, entonces, una intersección geométrica atraviesa los poemas de Tempo e eternidade que, entre lo extremadamente moderno y el dogma católico, diseña una poesía objetiva, hierática y esencial, que se hace cargo formalmente de la dimensión de lo sobrenatural. Lo interesante de esta lectura crítica de Tristão es que, una vez más, se percibe que el catolicismo y una modernidad "bien entendida" reniegan de la categoría de representación. Frente a la idolatría que pretende evocar en su figuración inanimada una fuerza oculta, los textos poéticos de Murilo Mendes y Jorge de Lima se entregan a la potencia vital del trazado icónico.

En efecto, a diferencia de las reminiscencias platónicas que plantean la existencia de un modelo o prototipo al que se intenta retener, los poemas-iconos de ambos escritores instauran, en el umbral entre lo animado y lo animado, una mirada y no un objeto: la posibilidad ver y ser visto. El despertar del poeta a otra realidad y su transformación en profeta es una imagen que aúna el poemario en su intento por expresar la configuración de una "nueva mirada" que le otorga a la modernidad la perspectiva de lo eterno. "Meu novo olhar" de Murilo Mendes, en este sentido, funciona como una suerte de poema manifiesto que no sólo da cuenta de su propia conversión al catolicismo, sino que también sostiene la necesaria relación entre lo visible y lo invisible, rehuyendo del realismo pero sin despreciar la materia. Esta lógica, que también es una de las definiciones posible del ícono, atraviesa el poemario en su dupla totalidad. A través del sintagma "Meu novo olhar é o de quem...", que se repite anafóricamente a lo largo del poema, el yo poético revela profética y, por momentos irónicamente, ciertas constantes del comportamiento humano, como ser: la separación entre los hombres, la dinamización de iglesias y su reconstrucción con fervor, el regreso de las masas a la guerra que consiguieron el pan y el cine, el sacrificio y la locura imperceptibles ${ }^{10}$. La valorización de la permanencia hace que ahora sí se pueda rechazar la tentación de los cuerpos femeninos, que lo alejaban de lo esencial en el poema del epígrafe:

\footnotetext{
${ }^{10}$ Dice el poema: "Meu novo olhar é o de quem já sabe/ Que alegria e ventura não permanecem./ Meu novo olhar é o de quem desvendou os tempos futuros / E viu neles a separação entre os homens,/ O filho contra o pai, a irmã contra o irmão, o amante contra a amante,/ As igrejas dinamitadas, depois reconstruídas com maior fervor;/ Meu novo olhar é o de quem atravessa a massa /E sabe que, depois dela ter obtido pão e cinema,/ Guerreará outra vez para não se entediar./Meu novo olhar é o de quem observa um casal belo e forte/ E sabe que, sozinhos, se amam os dois com nojo./Meu novo olhar é o de quem vê com tristesa a bailarina/ Que, para conseguir um movimento gracioso da perna,/ Durante anos sacrificou o resto do seu sêr./ Meu novo olhar é o de quem vê na criança andando/ A futuro doente, a orfã, a louca, a prostituta”. (LIMA Y MENDES, 1935, p. 77).
} 
Meu novo olhar é o de quem transpõe as musas de passagem

E não se detém mais nas ancas, nas nucas e nas coxas,

Mas se dilata à vista da Musa bela e serena,

A que me conduzirá ao amôr essencial.

Meu novo olhar é o de quem assistiu à paixão e morte do Amigo,

Poeta para toda a eternidade segundo a ordem de Jesus Cristo,

E aquêle que mudou a direção do meu olhar;

Meu novo olhar é o de quem já vê se desenrolar sua própria paixão e morte,

Esperando a integração do seu sêr definitivo

Sob o olhar fixo e incompreensível de Deus. (MENDES Y LIMA, 1935, p. 78)

No es tanto una invocación a Cristo lo que se busca al final, un aprisionamiento de su figura en el poema; al contrario, la voz poética se encarna en el Amigo y Poeta mayor, que Nery le había mostrado en su actualidad viva, haciendo tangible esa "restauración" que se prometía al comienzo del libro. Esta disolución moldea en el poeta la posibilidad de una nueva mirada que se vuelca hacia la abstracción. Así, el poema como ícono reclama que lo visible no es tan sólo lo sensible, y por esto se construye liminalmente siguiendo los contornos de las cosas perceptibles que acogen un contenido invisible a los ojos humanos. Y esta liminalidad señala lo infinito que convive y excede el horizonte de la modernidad.

En este sentido, los poemas de Jorge de Lima obsesivamente se empeñan en revelar que hay algo inmutable frente a los días que se suceden, como aparece en "Aceito as grandes palabras", donde el yo poético acepta los elementos modernos, como los cines, los tranvías, las playas, los flirts y la actualidad, pero le pide a Dios que: "Mas deixai-me ver no meio dessa conturbaçao/ o que está acima do tempo, o que é inmutavel” (LIMA Y MURILO, 1935, p. 27). Lo que está por encima del tiempo, pero también lo que lo antecede:

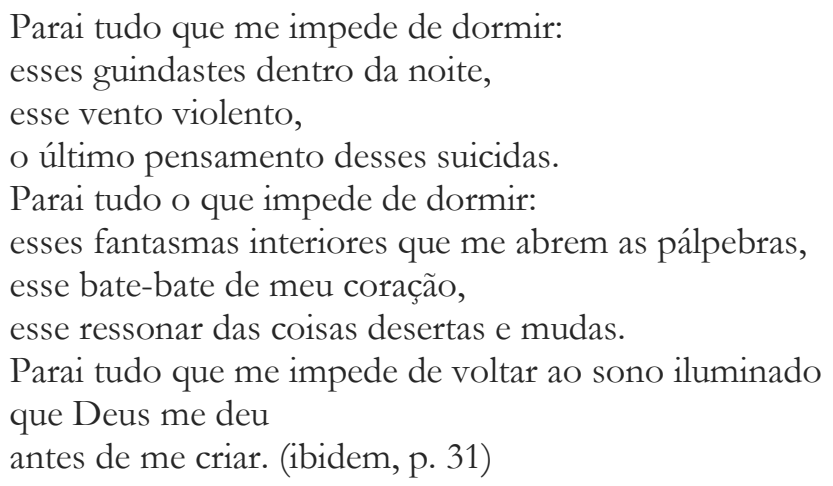

De resonancia surrealista, perceptible en su clima onírico (Cavalcanti, 2016), el poema clama por la fijeza y la inmovilidad que permita el encuentro con el "sueño iluminado" previo a la creación humana, que se pierde con el transcurrir de la vida. El despertar del poeta es también un descanso epifánico en lo eterno. Así, este sueño que antecede al sueño, más que inconsciente surreal, remite a un estadio preconsciente, lugar de tránsito, que alberga una suerte de memoria divina que late en la vigilia y necesita ser recordada. En su iconocidad, el poema de Jorge de Lima no le otorga al lector un lugar cómodo donde depositar la mirada, sino que por el contario provoca una visión vacía que se satura de lo invisible. Es por este motivo que la función del poeta es, como sugiere Murilo en "Vocação do poeta", mostrar de a poco la presencia de Dios en el mundo capitalista: 
Vim para garantir que a voz dos homens

Abafará a vos das sirenas das maquinas.

E que as palavras substanciais de Jesus Cristo

Dominarão as palavras do capitalista e do operario.

Vim para conhecer Deus meu Creador, pouco a pouco,

Pois si $\mathrm{O}$ viesse de repente, sem preparo, ficaria cégo! (ibidem: 81)

La fuerza anárquica del cristianismo, que desbarata los ideales del capitalismo y del comunismo, termina de fundar al poema como ícono, es decir, como emblema del poder de lo imago invisible que debe administrarse con cautela y rigor. En base al recorrido trazado, podríamos pensar que a Tempo e eternidade lo atraviesa un ascetismo poético que se vuelca hacia la abstracción: en sus poemas esto se comprueba desde el trazado de líneas horizontales y verticales que establecen cierto código binario con los elementos del mundo terrenal, hasta esas "flores carnívoras" de Jorge de Lima que se repiten y acechan la "planicie" sin comienzo ni fin. Así, lo plano toma la forma de la cruz a través de la túnica divina de brazos abiertos, como se lee en "Os ídolos se afogando": "Do Oriente ao Ocidente, perto do sol,/ estendamos uma túnica branca de braços abertos/ para significar: vinde a mim os que não conhecem patria,/ os que não sabem geografia nem contas de somar/ (....) Não veremos ídolos/porque os ídolos se afogaram nos rios rasos da planície" (ibidem: 37). La túnica inconsútil, nombre del próximo libro de poemas de Lima, dibuja un ángulo recto que conecta el cielo y la tierra, y desbarata todo tipo de clasificación: caen los líderes políticos, los límites geográficos, la idolatría de la razón y la ciencia. Como aclaman los últimos versos del "Poema essencialista" de Murilo: "O fim da ideia de propriedade, carne e tempo./ E a permanencia no absoluto e no inmutavel" (ibídem: 117).

\section{Conclusión: el camino a la abstracción}

Si hay un hilo rojo que aúna a Ismael Nery, Murilo Mendes y Jorge de Lima, este es, sin lugar a dudas, la posibilidad de deshacer la representación para que surja en su lugar una "imagen sin semejanza” que Gilles Deleuze (2007: 100) relaciona con el ícono, es decir, con la imagen en tanto presencia que excede toda visibilidad. De este modo, la tendencia hacia lo abstracto que se recupera a lo largo del libro escrito a cuatro manos se muestra inseparable del esencialismo de Nery que tanto impactó a Murilo Mendes y a Jorge de Lima, y se comprueba en esa disminución de los aspectos temporales o carnales que revelan una realidad más pura y universal.

Si la abstracción en su sentido estilístico, como sugiere Mondzian (2013), promueve un arte espiritual y viril, siempre fiel a su misión icónica, los poemas de Tiempo e eternidade combaten por una visibilidad autentica y protegida de cualquier idolatría sustentándose en el discurso de lo invisible. Las textualidades poéticas de Murilo y Jorge de Lima moldean de un modo continuo el material poético, ya que ejecutan un movimiento de expansión y fuga hacia lo esencial, y entregan una experiencia estética signada por la recuperación: se busca rescatar lo eterno y lo invisible como ordenación de un mundo que lleva inscripto un rastro nostálgico, es decir, restos de presencia de aquello que está ausente.

\section{Referências}

ABRIL, Manuel. "El arte moderno y los católicos", La Gaceta Literaria, n” 31, 1 de abril de 1928, p. 6. 

de 1928, p. 4.

. "Donde dicen que dije... digo...", La Gaceta Literaria, no 34, 15 de mayo

ANDRADE, Fábio de Souza. "Murilo Mendes e Jorge de Lima: Orfeu entre o tempo e a eternidade", in Ipotesi - Revista de Estudos Literários, n.1, enero./jun. 2002, pp.97-103.

ATHAYDE, Tristao de. "A Desforra do Espírito", en O Diário, 23 de junho de 1935.

CAVALCANTI DIAS, Luciano Marcos. "De Tempo e Eternidade à Invenção de Orfeu, Jorge de Lima em busca do tempo original”, in Signótica, Goiânia, v. 28, n. 1, jan./jun., 2016, pp. 99124.

DELEUZE, Gilles. Pintura: el concepto de diagrama. Buenos Aires: Cactus, 2007.

ESPINA, Antonio. "Encuesta sobre la nueva arquitectura", La Gaceta Literaria, n’32, 15 de abril de 1928, pp. 1 y 2. 1928, p. 7.

. "El arte de siempre y la espiritualidad", La Gaceta Literaria, no 33, 1 de mayo de

GRAHAM-DIXON, Andrew. Caravaggio. Una vida sagrada y profana. Madrid: Taurus, 2012. JESI, Furio. Spartakus. Simbología de la revuelta. Buenos Aires, Adriana Hidalgo, 2014.

LAFON, Michel y PEETERS, Benoît. Escribir en colaboración. Historias de dúos de escritores. Rosario: Beatriz Viterbo, 2008.

LIMA, Jorge y MENDES, Murilo. Tempo e eternidade. Porto Alegre: Livraria do Globo, 1935. MATTAR, Denise. Ismael Nery - Um Mito. In.: Ismael Nery - Em busca da essência. Almeida e Dale, 2015. Disponível em: http://www.colegiodearquitetos.com.br/wp-content/uploads/2017/04/11-ismael-nery.pdf

MENDES, Murilo. Poemas, São Paulo: Cosac Naify, 2014. . Recordações de Ismael Nery, São Paulo, Edusp, 1996.

. "Poema post-essencialista". A Ordem, No56, marzo de 1934, 422.

MONDZAIN, Marie-José. Imagem, icone, economia. As fontes bizantinas do imáginario contemporâneo. Rio de Janeiro: Contraponto, 2013.

NERY, Ismael. "Poemas de Ismael Nery (Recolhidos por Murilo Mendes)": "Poema Postessencialista", A Ordem, No57, febrero, 1934, p. 87.

. "Última página". A Ordem, No58, marzo de 1934, pp. 185-186.

SANTIAGO, Silviano. "Postfácio. Poesia fusão: catolicismo primitivo/ mentalidade moderna”, MENDES, Murilo. Poemas. São Paulo: Cosac Naify, 2014. 